Note

\title{
Effective Friedel-Crafts Acylation of Biotin Acid Chloride in Trifluoromethanesulfonic Acid
}

\author{
Yasuyuki Muto, Yuta Murai, Yasuko Sakinama, Yasuyuki Hashidoko, and Makoto Hashimoto ${ }^{\dagger}$ \\ Division of Applied Science, Graduate School of Agriculture, Hokkaido University, \\ Kita 9, Nishi 9, Kita-ku, Sapporo 060-8589, Japan
}

Received July 17, 2012; Accepted August 16, 2012; Online Publication, November 7, 2012

[doi:10.1271/bbb.120553]

\begin{abstract}
Biotin is one of the most useful tags in (bio)analytical science due to its specific interaction with avidin, but is not easy to convert because of its low solubility in most solvents. Friedel-Crafts acylation of biotin acid chloride in triflic acid was examined, and the synthesized derivatives had stronger affinity to avidin than biotin in a binding assay using 2-(4'-hydroxyphenylazo)benzoic acid.
\end{abstract}

Key words: biotin; avidin; Friedel-Crafts acylation; triflic acid; 2-(4'-hydroxyphenylazo)benzoic acid

Biotin-(strept)avidin interaction is widely used with a specific tag for exogenous ligands in bioanalysis. ${ }^{1)}$ Chemical modification of biotin molecules has been used via amide formation in its carboxylic acid moiety with a polar aprotic solvent due to the low solubility of biotin in many organic solvents. ${ }^{2)}$ The major derivatives of biotin have been reported as amides formed between carboxylic acid in biotin and amino compounds. Biotin derivation under other conditions is not effective due to its low solubility in most solvents. ${ }^{2)}$ It has recently been reported that the biotin carboxylic group was converted to a terminal alkyne, which utilized $\mathrm{C}-\mathrm{C}$ bond formation with Heck-Sonogashira coupling, although the approach needed many derivation steps for biotin. ${ }^{3}$ )

The amide derivative of biotin is well known as the substrate of the biotinidase which is contained in serum. ${ }^{4)}$ Although biotinylation via the amide bond is a widespread method for chemical the modification of bioactive compounds, each of these compounds is a substrate for endogenous biotinidase. Other derivatives of biotin must therefore be established. Changing the amide bond to another functional group would be useful to prevent biotinidase hydrolysis. Although an amide displaced to a ketone is one of the choices, there are very few examples of the conversion of the carboxylic acid of biotin to a ketone by Friedel-Crafts acylation, this being one of the classical synthetic methods for preparing an acetophenone skeleton from aromatics and carboxylic acids. ${ }^{5)}$ It has not previously been reported that the biotin derivatives have been subjected to Friedel-Crafts acylation with simple aromatics (benzene, toluene, etc.). It can be assumed that biotin solubility in organic solvents prevented the Friedel-Crafts reaction. It has recently been reported that the mixed anhydride generated from biotin and trifluoroacetic acid in situ could react with electron-rich acyl acceptors (ferrocene, ruthenocene and pyrene) in the presence of an equivalent of trifluoromethanesulfonic acid $(\mathrm{TfOH})$ in dichloromethane in a moderate yield $(<55 \%) .{ }^{6}$ ) The authors described that the high reactivity of the electron-rich acyl acceptors promoted Friedel-Crafts acylation (e.g., ferrocene and pyrene were respectively $3.3 \times 10^{6}$ and 220 times more reactive than benzene) for effective Friedel-Crafts reactions. We found that biotin derivatives dissolved well in $\mathrm{TfOH}$ and have reported that using $\mathrm{TfOH}$ as both a catalyst and solvent markedly enhanced the Friedel-Crafts acylation of amino acid derivatives which are insoluble in the appropriate solvent for the Friedel-Crafts reaction. ${ }^{7-11)}$

We report in this paper effective Friedel-Crafts acylation reactions of in situ generated biotin acid chloride $\mathbf{2}$ and monocyclic aromatics in TfOH under mild conditions to prevent biotinidase hydrolysis of the synthetic compounds. Furthermore, the Fridel-Crafts products were subjected to a 2-(4'-hydroxyphenylazo)benzoic acid (HABA) assay to elucidate the binding properties of the synthetic compounds to avidin.

Biotin acid chloride $2,{ }^{2)}$ which is one of the most suitable species for Friedel-Crafts acylation, was easily prepared from thionyl chloride and then subjected to Friedel-Crafts acylation with benzene $\mathbf{3}$ in TfOH. A slightly excess amount (1.7 eq) of benzene was used due to its volatile character. The isolated yield of $\mathbf{8}$ was improved in a temperature-dependent manner, 43\%, $70 \%$ and $83 \%$ at 50,80 and $100{ }^{\circ} \mathrm{C}$, respectively, in $1 \mathrm{~h}$ (Table 1, entry 1-3). Toluene 4 and xylenes 5-7, which are more reactive acyl acceptors than benzene, respectively afforded Friedel-Crafts products 9-12 under milder conditions $\left(1.7 \mathrm{eq}, 50^{\circ} \mathrm{C}, 1 \mathrm{~h}\right)$ with outstanding isolated yields (86-95\%) compared with that of benzene (Table 1, entry 4-7). No regioisomer for compound 9 and $\mathbf{1 0}$ could be detected in the reaction mixture.

Anisole 13, which is a more activated acyl acceptor, was subjected to milder conditions for Friedel-Crafts acylation. The same conditions as those used for toluene and xylene $\left(1.7 \mathrm{eq}, 50^{\circ} \mathrm{C}, 1 \mathrm{~h}\right)$ resulted in a low yield of $43 \%$ (Table 2 , entry 1 ). This yield improved when the reaction was performed at room temperature with $1.7 \mathrm{eq}$ of anisole or at $0{ }^{\circ} \mathrm{C}$ with $3.4 \mathrm{eq}$ of anisole (about $80 \%$ ) (Table 2, entries 2-4). 1,2-Dimethoxybenzene 14 reacted more rapidly than anisole $\left(0^{\circ} \mathrm{C}, 10 \mathrm{~min}\right)$ (Table 2 , entries 7 and 8). The isolated yield was decreased in the presence of excess aromatics (Table 2, entries 5 and 6).

$\dagger$ To whom correspondence should be addressed. Tel/Fax: +81-11-706-3849; E-mail: hasimoto@abs.agr.hokudai.ac.jp 
Table 1. Friedel-Crafts Reaction of Aromatics and Biotin in TfOH

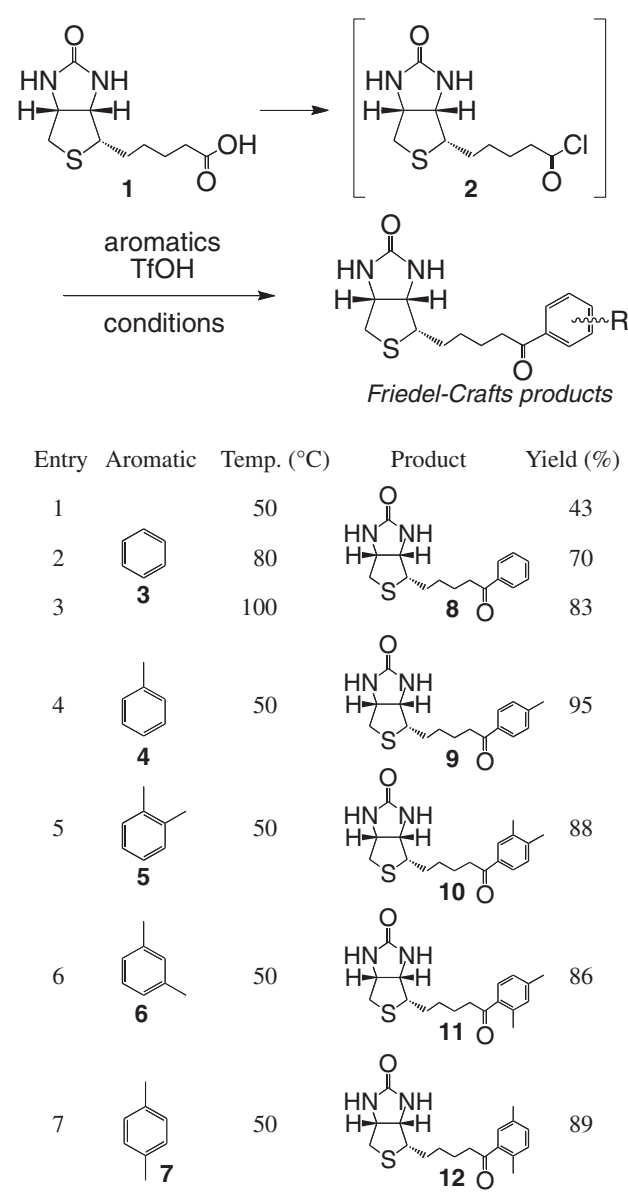

Table 2. Friedel-Crafts Reaction of Anisole Derivatives 13 and 14 and Biotin in $\mathrm{TfOH}$

\begin{tabular}{|c|c|c|c|c|c|c|}
\hline Entry & $\begin{array}{c}\text { Aromatic } \\
\text { (eq) }\end{array}$ & & $\begin{array}{l}\text { Temp. } \\
\left({ }^{\circ} \mathrm{C}\right)\end{array}$ & $\begin{array}{l}\text { Time } \\
(\min )\end{array}$ & Product & $\begin{array}{c}\text { Yield } \\
(\%)\end{array}$ \\
\hline 1 & & (1.7) & 50 & 60 & & 43 \\
\hline 2 & & (1.7) & $\mathrm{rt}$ & 60 & & 78 \\
\hline 3 & & (3.4) & $\mathrm{rt}$ & 20 & & 58 \\
\hline 4 & 13 & (3.4) & 0 & 60 & 15 & 80 \\
\hline 5 & & (6.8) & 0 & 10 & & 22 \\
\hline 6 & & (3.4) & 0 & 10 & & 50 \\
\hline 7 & $\mathrm{OMe}$ & (2.5) & 0 & $10 \stackrel{\mathrm{H}}{\mathrm{H}}$ & $\mathrm{NH}$ & 72 \\
\hline 8 & & (1.7) & 0 & 0 & & 72 \\
\hline 9 & 14 & (1.7) & -20 & 10 & 16 & 65 \\
\hline 10 & & (1.7) & -40 & 10 & & 50 \\
\hline
\end{tabular}

No improvement was apparent when the reaction was performed at a lower temperature $\left(-20\right.$ or $\left.-40^{\circ} \mathrm{C}\right)$ (Table 2, entries 8 and 9). Bromobenzene was also subjected to the Friedel-Crafts reaction under the same conditions as those just described. The main products were a mixture consisting of the desired $p$-bromo derivative and debromo compound $\mathbf{8}$ in a 2:1 ratio.

We evaluated the binding properties of the synthetic compounds (8-12, 15 and 16) to avidin in a solution. Competitive replacement of HABA with a synthetic biotin derivative provides a convenient spectroscopic

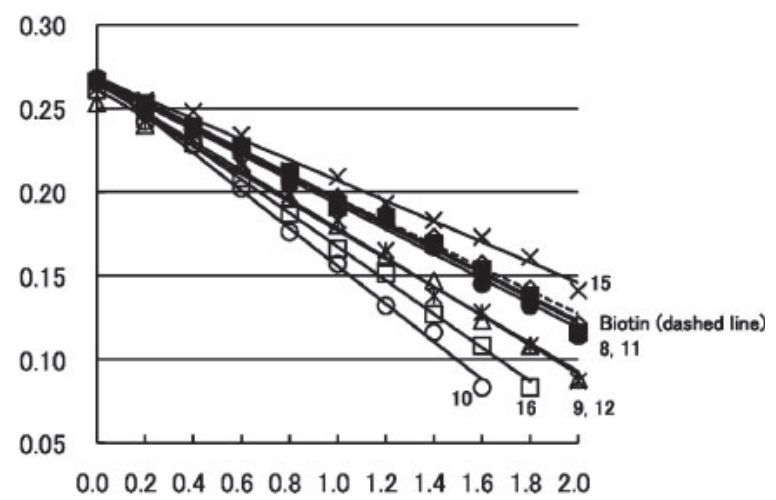

Scheme 1. Titration of the Avidin-HABA Complex with Synthetic Biotin Derivatives 8-12, 15 and $\mathbf{1 6 .}$

The biotin result is represented by an unfilled diamond and dashed line. The assay results for synthetic compounds are presented as follow: 8, filled square; 9, unfilled triangle; 10, unfilled circle; 11, filled circle; 12, asterisk; 15, cross; and 16, unfilled square.

method for assessing binding to avidin. HABA forms a complex with the biotin-binding site of avidin in a solution which is characterized by an absorbance at $500 \mathrm{~nm}$ in a 96-well plate. Displacement of HABA by biotin results in decreased absorbance at $500 \mathrm{~nm}$. This method is widely used as a qualitative assay for evaluating biotinylated compounds. ${ }^{12)}$ The results of the HABA assay are summarized as follow (Scheme 1): 1, compound $\mathbf{1 5}$ had less binding potential to biotin; 2, compounds $\mathbf{8}$ and $\mathbf{1 1}$ had similar binding potential to biotin; 3, compounds 9 and $\mathbf{1 2}$ had slightly higher binding potential to biotin; 4 , di-substituted aromatics at the $m$ - and $p$-positions against the carbonyl group of biotin (10 and 16) had higher binding properties than biotin.

To the best of our knowledge, the previously reported biotin derivatives, with the carboxylic acid moiety deleted, had lower avidin binding potential than native biotin. Many of our synthetic compounds had stronger avidin binding potential than biotin. The strongest compounds had an $m$ - and $p$-disubstituent against the carbonyl moiety. The results show that the structural similarity between HABA and the $m$ - and $p$-disubstituted aromatic ring moiety of $\mathbf{1 0}$ and $\mathbf{1 6}$ promoted competitive inhibition. Although 3,4-dimethylacetophenone was also subjected to the HABA assay, no competitive inhibition was apparent. These results indicate the stronger competitive inhibition of compounds $\mathbf{1 0}$ and $\mathbf{1 6}$ than of mother skeleton biotin derived from all parts of the compounds.

Effective conversion of the carboxylic acid of biotin to aryl ketones by the Friedel-Crafts reaction and their adequate binding affinity to avidin will encourage research into the use of these novel modifications to biotin as bioanalysis tools.

\section{Experimental}

General methods. ${ }^{1} \mathrm{H}$ - and ${ }^{13} \mathrm{C}$-NMR spectra were measured by a Jeol ECA 500 spectrometer for structural determination. Chemical shifts in the ${ }^{1} \mathrm{H}-\mathrm{NMR}$ spectra are expressed in ppm downfield from the signal for tetramethylsilane used as an internal standard. Splitting patterns are designated by $\mathrm{s}$ (singlet), $\mathrm{d}$ (doublet), $\mathrm{t}$ (triplet), and $\mathrm{m}$ (multiplet). The ${ }^{13} \mathrm{C}$ chemical shifts of the solvents in the ${ }^{13} \mathrm{C}-\mathrm{NMR}$ spectra were used as the internal standard $\left({ }^{13} \mathrm{CDCl}_{3}, 77.0 \mathrm{ppm}\right)$. MS data were obtained with a Waters LCT Premier XE instrument. 
Typical synthetic procedure: d-Biotin $(0.2 \mathrm{mmol})$ was suspended in thionyl chloride $(0.8 \mathrm{~mL})$, and the reaction mixture was stirred at room temperature for an hour, before being concentrated. A mixture of the residue and aromatic compound (1.7 eq) was dissolved in $\mathrm{TfOH}(1 \mathrm{~mL})$ at $0^{\circ} \mathrm{C}$. The reaction mixture was stirred at the indicated temperature and then poured into a mixture of water and ethyl acetate. The organic layer was washed with saturated $\mathrm{NaCl}$, dried over $\mathrm{MgSO}_{4}$, filtered and concentrated. The resulting residue was subjected to silica column chromatography to afford a pure product.

$(3 a \mathrm{~S}, 4 \mathrm{~S}, 6 a \mathrm{R})-4-(5-O x o-5-p h e n y l p e n t y l)$ tetrahydro-1H-thieno[3,4-d]imidazol-2(3H)-one $(8) .{ }^{1} \mathrm{H}-\mathrm{NMR}\left(\mathrm{CDCl}_{3}\right) \delta: 7.96(2 \mathrm{H}, \mathrm{d}, J=7.4 \mathrm{~Hz})$, $7.56(1 \mathrm{H}, \mathrm{t}, J=7.4 \mathrm{~Hz}), 7.46(2 \mathrm{H}, \mathrm{t}, J=7.4 \mathrm{~Hz}), 5.80(1 \mathrm{H}, \mathrm{s}), 5.37$ $(1 \mathrm{H}, \mathrm{s}), 4.51(1 \mathrm{H}, \mathrm{m}), 4.33(1 \mathrm{H}, \mathrm{m}), 3.18(1 \mathrm{H}, \mathrm{m}), 3.01(2 \mathrm{H}, \mathrm{t}$, $J=7.4 \mathrm{~Hz}), 2.92(1 \mathrm{H}, \quad \mathrm{dd}, \quad J=4.9,12.9 \mathrm{~Hz}), 2.73 \quad(1 \mathrm{H}, \quad \mathrm{d}$, $J=12.9 \mathrm{~Hz}), 1.88-1.44(6 \mathrm{H}, \mathrm{m}) ;{ }^{13} \mathrm{C}-\mathrm{NMR}\left(\mathrm{CDCl}_{3}\right) \delta: 200.34$, 163.55, 136.88, 133.04, 128.61, 128.08, 61.94, 60.10, 55.40, 40.60, 38.14, 28.54, 28.45, 24.10; HRESIMS $m / z 305.1324[\mathrm{M}+\mathrm{H}]^{+}$(calcd. for $\left.\mathrm{C}_{16} \mathrm{H}_{21} \mathrm{~N}_{2} \mathrm{O}_{2} \mathrm{~S}, 305.1318\right)$.

$(3 a \mathrm{~S}, 4 \mathrm{~S}, 6 a \mathrm{R})-4-(5-O x o-5-($ p-tolyl)pentyl)tetrahydro-1H-thieno[3,4d]-imidazol-2(3H)-one (9). ${ }^{1} \mathrm{H}-\mathrm{NMR} \quad\left(\mathrm{CDCl}_{3}\right) \quad \delta: 7.85 \quad(2 \mathrm{H}, \mathrm{d}$, $J=8.0 \mathrm{~Hz}), 7.25(2 \mathrm{H}, \mathrm{d}, J=8.0 \mathrm{~Hz}), 6.19(1 \mathrm{H}, \mathrm{s}), 5.81(1 \mathrm{H}, \mathrm{s})$, $4.49(1 \mathrm{H}, \mathrm{m}), 4.31(1 \mathrm{H}, \mathrm{m}), 3.18(1 \mathrm{H}, \mathrm{m}), 2.97(2 \mathrm{H}, \mathrm{t}, J=7.2 \mathrm{~Hz})$, $2.90(1 \mathrm{H}, \mathrm{dd}, J=5.2,12.6 \mathrm{~Hz}), 2.72(1 \mathrm{H}, \mathrm{d}, J=12.6 \mathrm{~Hz}), 2.40(3 \mathrm{H}$, s), $1.86-1.44(6 \mathrm{H}, \mathrm{m}) ;{ }^{13} \mathrm{C}-\mathrm{NMR}\left(\mathrm{CDCl}_{3}\right) \delta: 200.03,163.89,143.69$, $134.32,129.19,128.13,61.89,60.06,55.43,40.54,38.00,28.50$, 28.35, 24.16, 21.57; HRESIMS $m / z 319.1480[\mathrm{M}+\mathrm{H}]^{+}$(calcd. for $\left.\mathrm{C}_{17} \mathrm{H}_{23} \mathrm{~N}_{2} \mathrm{O}_{2} \mathrm{~S}, 319.1475\right)$.

(3aS,4S,6aR)-4-(5-(3,4-Dimethylphenyl)-5-oxopentyl)tetrahydro-1Hthieno[3,4-d]imidazol-2(3H)-one $(\mathbf{1 0}) .{ }^{1} \mathrm{H}-\mathrm{NMR}\left(\mathrm{CDCl}_{3}\right) \delta: 7.72(1 \mathrm{H}$, s), $7.68(1 \mathrm{H}, \mathrm{d}, J=8.0 \mathrm{~Hz}), 7.19(1 \mathrm{H}, \mathrm{d}, J=8.0 \mathrm{~Hz}), 6.36(1 \mathrm{H}, \mathrm{s})$, $6.07(1 \mathrm{H}, \mathrm{s}), 4.48(1 \mathrm{H}, \mathrm{m}), 4.30(1 \mathrm{H}, \mathrm{m}), 3.17(1 \mathrm{H}, \mathrm{m}), 2.95(2 \mathrm{H}, \mathrm{t}$, $J=7.4 \mathrm{~Hz}), 2.89(1 \mathrm{H}, \mathrm{dd}, J=5.2,13.2 \mathrm{~Hz}), 2.72(1 \mathrm{H}, \mathrm{d}, J=$ $13.2 \mathrm{~Hz}), 2.30(6 \mathrm{H}, \mathrm{s}), 1.84-1.44(6 \mathrm{H}, \mathrm{m}) ;{ }^{13} \mathrm{C}-\mathrm{NMR}\left(\mathrm{CDCl}_{3}\right) \delta$ : 200.24, 164.03, 142.33, 136.74, 134.65, 129.63, 129.02, 125.70, 61.83, $60.02, \quad 55.41,40.47,37.96,28.45,28.28,24.14,19.89,19.67$; HRESIMS $m / z \quad 333.1642[\mathrm{M}+\mathrm{H}]^{+}$(calcd. for $\mathrm{C}_{18} \mathrm{H}_{25} \mathrm{~N}_{2} \mathrm{O}_{2} \mathrm{~S}$, 333.1637).

(3aS,4S,6aR)-4-(5-(2,4-Dimethylphenyl)-5-oxopentyl)tetrahydro-1Hthieno[3,4-d]imidazol-2(3H)-one $(\mathbf{1 1}) .{ }^{1} \mathrm{H}-\mathrm{NMR}\left(\mathrm{CDCl}_{3}\right) \delta: 7.58(1 \mathrm{H}$, $\mathrm{d}, J=8.0 \mathrm{~Hz}), 7.04(1 \mathrm{H}, \mathrm{d}, J=8.0 \mathrm{~Hz}), 7.03(1 \mathrm{H}, \mathrm{s}), 6.37(1 \mathrm{H}, \mathrm{s})$, $6.06(1 \mathrm{H}, \mathrm{s}), 4.48(1 \mathrm{H}, \mathrm{m}), 4.29(1 \mathrm{H}, \mathrm{m}), 3.16(1 \mathrm{H}, \mathrm{m}), 2.90(2 \mathrm{H}, \mathrm{t}$, $J=7.2 \mathrm{~Hz}), 2.88(1 \mathrm{H}, \mathrm{dd}, J=5.2,12.6 \mathrm{~Hz}), 2.70(1 \mathrm{H}, \mathrm{d}, J=$ $12.6 \mathrm{~Hz}), 2.47(3 \mathrm{H}, \mathrm{s}), 2.34(3 \mathrm{H}, \mathrm{s}), 1.82-1.42(6 \mathrm{H}, \mathrm{m}) ;{ }^{13} \mathrm{C}-\mathrm{NMR}$ $\left(\mathrm{CDCl}_{3}\right) \delta: 203.75,164.04,141.62,138.33,134.76,132.69,128.96$, 126.17, 61.86, 60.02, 55.44, 40.74, 40.45, 28.49, 28.33, 24.27, 21.46, 21.23; HRESIMS $m / z 333.1614[\mathrm{M}+\mathrm{H}]^{+}$(calcd. for $\mathrm{C}_{18} \mathrm{H}_{25} \mathrm{~N}_{2} \mathrm{O}_{2} \mathrm{~S}$, 333.1637).

(3aS,4S,6aR)-4-(5-(2,5-Dimethylphenyl)-5-oxopentyl)tetrahydro-1Hthieno[3,4-d]imidazol-2(3H)-one $(12) .{ }^{1} \mathrm{H}-\mathrm{NMR}\left(\mathrm{CDCl}_{3}\right) \delta: 7.41(1 \mathrm{H}$, s), $7.17(1 \mathrm{H}, \mathrm{d}, J=8.0 \mathrm{~Hz}), 7.11(1 \mathrm{H}, \mathrm{d}, J=8.0 \mathrm{~Hz}), 6.15(1 \mathrm{H}, \mathrm{s})$, $5.83(1 \mathrm{H}, \mathrm{s}), 4.49(1 \mathrm{H}, \mathrm{m}), 4.30(1 \mathrm{H}, \mathrm{m}), 3.17(1 \mathrm{H}, \mathrm{m}), 2.90(2 \mathrm{H}, \mathrm{t}$, $J=7.4 \mathrm{~Hz}), \quad 2.89 \quad(1 \mathrm{H}, \quad \mathrm{dd}, \quad J=5.2, \quad 13.2 \mathrm{~Hz}), 2.71 \quad(1 \mathrm{H}, \quad \mathrm{d}$, $J=13.2 \mathrm{~Hz}), 2.42(3 \mathrm{H}, \mathrm{s}), 2.36(3 \mathrm{H}, \mathrm{s}), 1.81-1.43(6 \mathrm{H}, \mathrm{m}) ;{ }^{13} \mathrm{C}-$ NMR $\left(\mathrm{CDCl}_{3}\right) \delta: 204.76,164.00,137.93,135.03,134.47,131.72$, $131.65,128.80,61.89,60.02,55.44,41.11,40.46,28.49,28.34,24.10$, 20.83, 20.68; HRESIMS $m / z \quad 333.1609 \quad[\mathrm{M}+\mathrm{H}]^{+}$(calcd. for $\left.\mathrm{C}_{18} \mathrm{H}_{25} \mathrm{~N}_{2} \mathrm{O}_{2} \mathrm{~S}, 333.1637\right)$.

(3aS,4S,6aR)-4-(5-(4-Methoxyphenyl)-5-oxopentyl)tetrahydro-1Hthieno[3,4-d]imidazol-2(3H)-one (15). ${ }^{1} \mathrm{H}-\mathrm{NMR}\left(\mathrm{CDCl}_{3}\right) \delta: 7.94(2 \mathrm{H}$, $\mathrm{d}, J=9.2 \mathrm{~Hz}), 6.94(2 \mathrm{H}, \mathrm{d}, J=9.2 \mathrm{~Hz}), 5.37(1 \mathrm{H}, \mathrm{s}), 5.02(1 \mathrm{H}, \mathrm{s})$, $4.52(1 \mathrm{H}, \mathrm{m}), 4.33(1 \mathrm{H}, \mathrm{m}), 3.87(3 \mathrm{H}, \mathrm{s}), 3.20(1 \mathrm{H}, \mathrm{s}), 2.95(2 \mathrm{H}, \mathrm{t}$,
$J=7.4 \mathrm{~Hz}), 2.93(1 \mathrm{H}, \mathrm{dd}, J=13.5,5.4 \mathrm{~Hz}), 2.73(1 \mathrm{H}, \mathrm{d}, J=$ $13.5 \mathrm{~Hz}), 1.83-1.46(6 \mathrm{H}, \mathrm{m}) ;{ }^{13} \mathrm{C}-\mathrm{NMR}\left(\mathrm{D}_{2} \mathrm{O}\right) \delta: 203.38,175.88$, $121.72,119.24,116.69,114.17,66.22,58.93,55.89,53.82,49.13$, 35.79, 24.85, 23.96, 22.41; HRESIMS $m / z 335.1429[\mathrm{M}+\mathrm{H}]^{+}$(calcd. for $\left.\mathrm{C}_{17} \mathrm{H}_{23} \mathrm{~N}_{2} \mathrm{O}_{3} \mathrm{~S}, 335.1424\right)$.

(3aS,4S,6aR)-4-(5-(3,4-Dimethoxyphenyl)-5-oxopentyl)tetrahydro1H-thieno[3,4-d] imidazol-2(3H)-one (16). ${ }^{1} \mathrm{H}-\mathrm{NMR}\left(\mathrm{CDCl}_{3}\right) \delta: 7.56$ $(1 \mathrm{H}, \mathrm{d}, J=9.2 \mathrm{~Hz}), 7.48(1 \mathrm{H}, \mathrm{s}), 6.86(1 \mathrm{H}, \mathrm{d}, J=9.2 \mathrm{~Hz}), 6.20(1 \mathrm{H}$, s), $5.78(1 \mathrm{H}, \mathrm{s}), 4.51(1 \mathrm{H}, \mathrm{m}), 4.32(1 \mathrm{H}, \mathrm{m}), 3.95(3 \mathrm{H}, \mathrm{s}), 3.94(3 \mathrm{H}, \mathrm{s})$, $3.19(1 \mathrm{H}, \mathrm{m}), 2.92(2 \mathrm{H}, \mathrm{t}, J=7.2 \mathrm{~Hz}), 2.87(1 \mathrm{H}, \mathrm{dd}, J=5.2,13.2 \mathrm{~Hz})$, $2.70(1 \mathrm{H}, \mathrm{d}, J=13.2 \mathrm{~Hz}), 1.89-1.42(6 \mathrm{H}, \mathrm{m}) ;{ }^{13} \mathrm{C}-\mathrm{NMR}\left(\mathrm{CDCl}_{3}\right)$ $\delta: 198.99,163.88,153.06,148.85,130.01,122.73,109.95,109.88$, $61.88,60.06,55.99,55.91,55.43,40.53,37.59,28.50,28.34,24.42$; HRESIMS $m / z \quad 365.1535[\mathrm{M}+\mathrm{H}]^{+}$(calcd. for $\mathrm{C}_{18} \mathrm{H}_{25} \mathrm{~N}_{2} \mathrm{O}_{4} \mathrm{~S}$, 365.1530).

HABA assay. Avidin was dissolved in PBS $(0.05 \mathrm{M}$ sodium phosphate, $0.15 \mathrm{M} \mathrm{NaCl}, \mathrm{pH} 7.2$ ) at a concentration of $0.5 \mathrm{mg} / \mathrm{mL}$. A solution of 2-(4-hydroxyphenylazo)-benzoic acid (HABA) was made by dissolving the dye in a $10 \mathrm{mM} \mathrm{NaOH}$ solution at a concentration of $2.42 \mathrm{mg} / \mathrm{mL}$. Each biotin derivative $(0.2 \mathrm{mM})$ in PBS was treated with a mixture $(0.1 \mathrm{~mL})$ of the avidin solution and HABA solution $(40: 1)$ with a final volume of $0.14 \mathrm{~mL}$ per well (96-well plate). The decrease in absorbance at $500 \mathrm{~nm}$ of the solution was plotted as a function of each added biotin derivative to generate a standard response curve.

\section{Acknowledgments}

This study was partially supported by grants for scientific research (C), 19510210 and 21510219, from the Ministry of Education, Culture, Sports, Science and Technology of Japan.

\section{References}

1) Wilchek $\mathrm{M}$ and Bayer EA, Methods Enzymol., 184, 5-13 (1990).

2) Bayer EA, Ben-Hur H, and Wilchek M, Methods Enzymol., 184, 80-89 (1990).

3) Corona C, Bryant BK, and Arterburn JB, Org. Lett., 8, 18831886 (2006).

4) Wolf B, Hymes J, and Heard GS, Methods Enzymol., 184, 103111 (1990).

5) For a recent review, see: Satori G and Maggi R, Advances in Friedel-Crafts Acylation Reactions: Catalytic and Green Processes, CRC Press, Boca Raton (2010).

6) Plazuk D, Zakrzewski J, and Salmain M, Org. Biomol. Chem., 9, 408-417 (2011).

7) Murashige R, Hayashi Y, and Hashimoto M, Tetrahedron Lett., 49, 6566-6568 (2008).

8) Murai Y, Hatanaka Y, Kanaoka Y, and Hashimoto M, Heterocycles, 79, 359-364 (2009).

9) Murashige R, Murai Y, Hatanaka Y, and Hashimoto M, Biosci. Biotechnol. Biochem., 73, 1377-1380 (2009).

10) Murashige R, Hayashi Y, Ohmori S, Torii A, Aizu Y, Muto Y, Murai Y, Oda Y, and Hashimoto M, Tetrahedron, 67, 641-649 (2011).

11) Murai Y, Hashidoko $Y$, and Hashimoto M, Biosci. Biotechnol. Biochem., 75, 352-354 (2011).

12) Green NM, Methods Enzymol., 18A, 418-424 (1970). 